\title{
Hydrodynamic Model of the Open-Pit Mine "Buvač" (Republic of Srpska)
}

\author{
Dušan Polomčić, Dragoljub Bajič*, Petar Papić, Jana Stojković \\ University of Belgrade, Faculty of Mining and Geology, Department of Hydrogeology \\ e-mail: osljane@orion.rs
}

\begin{abstract}
Cite as: Polomcic, D., Bajic, D., Papic, P., Stojkovic, J., Hydrodynamic model of the open-pit mine "Buvač” (Republic of Srpska), J. sustain. dev. energy water environ. syst., 1(3), pp 260-271, 2013, DOI:
\end{abstract} http://dx.doi.org/10.13044/j.sdewes.2013.01.0019

\begin{abstract}
Projecting of the dewatering system of the open-pit mine "Buvač" (Republic of Srpska, Bosnia and Herzegovina) is based on the use of hydrodynamic model of groundwater regime. Creating the hydrodynamic model of the open-pit mine "Buvač" was made in phases, which began by basic interpretation of collected data, along with schematization of the groundwater flow and flow conditions, and finally, forming and calibration of model. Hydrodynamic model was created as multilayer model with eight layers. Calibration of the hydrodynamic model is the starting point for making prognosis calculation in order to create the most optimal system of open-pit mine protection from groundwater. The results of model calibration indicated that the rivers Gomjenica and Bistrica, precipitation and inflow from karstified rocks are the primary sources of recharge of the limonite ore body "Buvač".
\end{abstract}

\section{KEYWORDS}

Limonite ore body, Aquifers, Model calibration, Groundwater balance

\section{INTRODUCTION}

The limonite ore body "Buvač" is part of the Omarska deposit that also includes Jezero and Mamuze ore bodies SE in Omarska field. The Buvač body is Carboniferous, of 20 metres average thickness and some $3 \mathrm{~km}^{2}$ in surface area. Fig. 1 shows location of the research area.

Extraction of limonite and associated sediments at "Buvač" deposit is being performed under complex hydrogeological conditions, thus in the final exploitation phase the open pit depth is going to be $150 \mathrm{~m}$. Lowering of mining level will basically disclose all water-bearing sediments, which must be previously drained, in order to provide level stability, as well as equipment and mining staff protection during the deposit exploitation.

In mining operations carrying out below the water table, mine operators are potentially faced with two important water-related problems. These are the amount and pressure of groundwater that could flow into an open pit and the effect of pore water pressure on the stability of an open pit high wall. Many analytical solutions for prediction of water inflow into mine excavations can be found in the literature [1-3]. These models often were developed based on some very specific assumptions and boundary conditions that restrict their applicability in many mining situations.

The prediction of the amount of water inflow into the open-pit mine is very important for development of a mine dewatering program. Moreover, taking into account that the analytical solutions are not as versatile as numerical methods, which can deal with complex mining situations, so, it is necessary to develop a numerical (hydrodynamic) model that 
includes all aquifer conditions [4]. Numerical models have not the limitations of analytical solutions and they are suitable for the simulation of all aquifer conditions. Furthermore, numerical models can provide a more realistic representation of the interaction between groundwater systems and mine excavations.

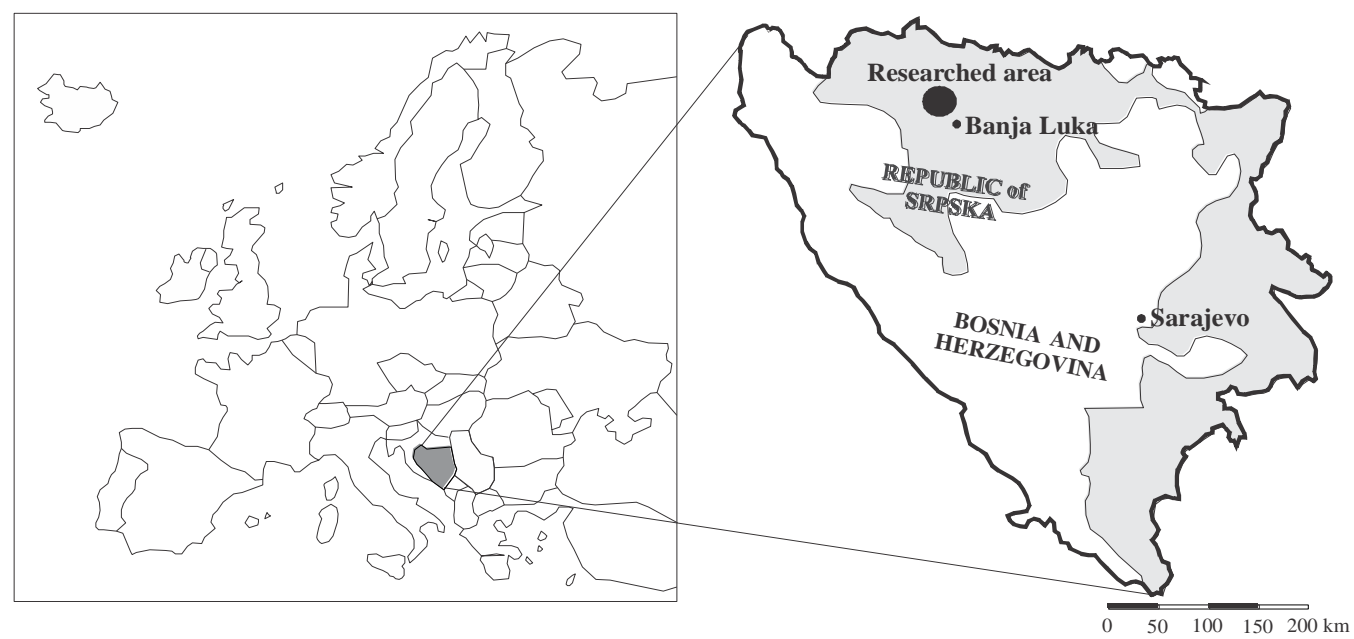

Figure 1. Location map of the researched area

Projecting of the dewatering system of the open-pit mine "Buvač" is based on the use of hydrodynamical model of groundwater regime. The results of numerical simulations would be used, in future, to develop an appropriate water management strategy in order to minimise the operational problems below the water surface and long-term environmental problems and solutions to ensure the stability of an open pit high wall [5, 6].

\section{HYDROGEOLOGY CHARACTERISTICS}

Characteristics of aquifers, hydraulic and storage properties are deduced from more than 550 cored boreholes (Fig. 2). Hydrogeologic characterization of the "Buvač" open-pit mine are interpreted from all geological and hydrogeological investigation and laboratory test data.

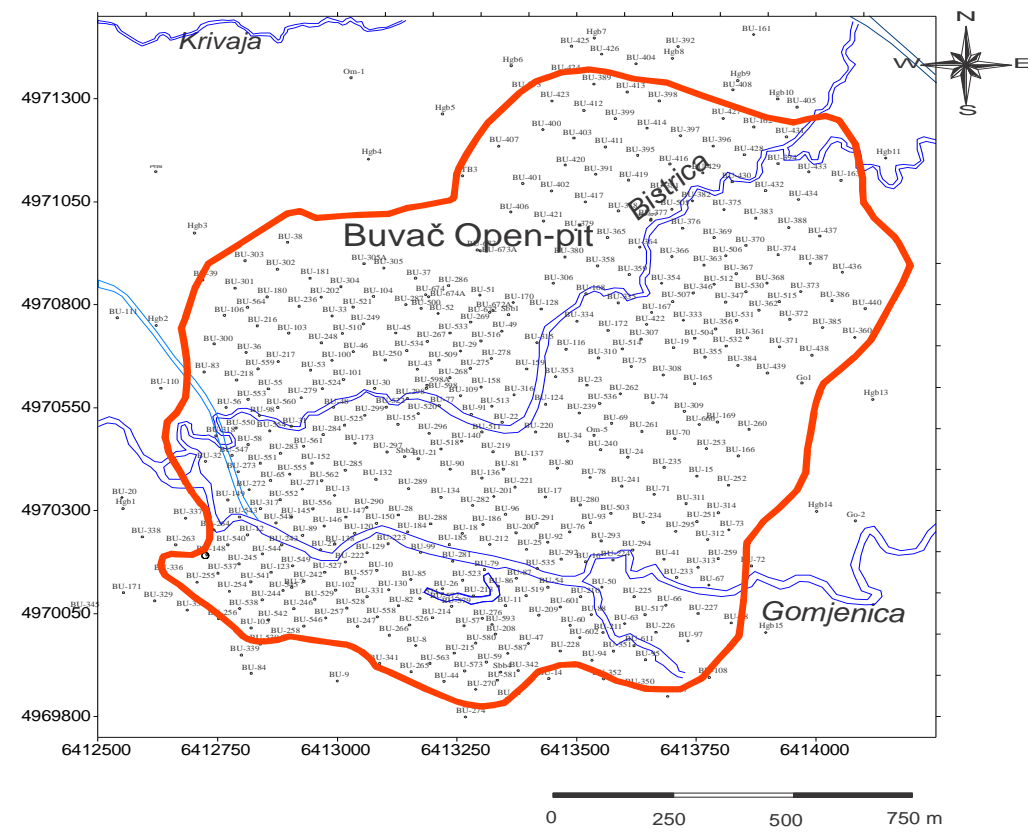

Figure 2. Test borehole sites in the Buvač limonite deposit area 


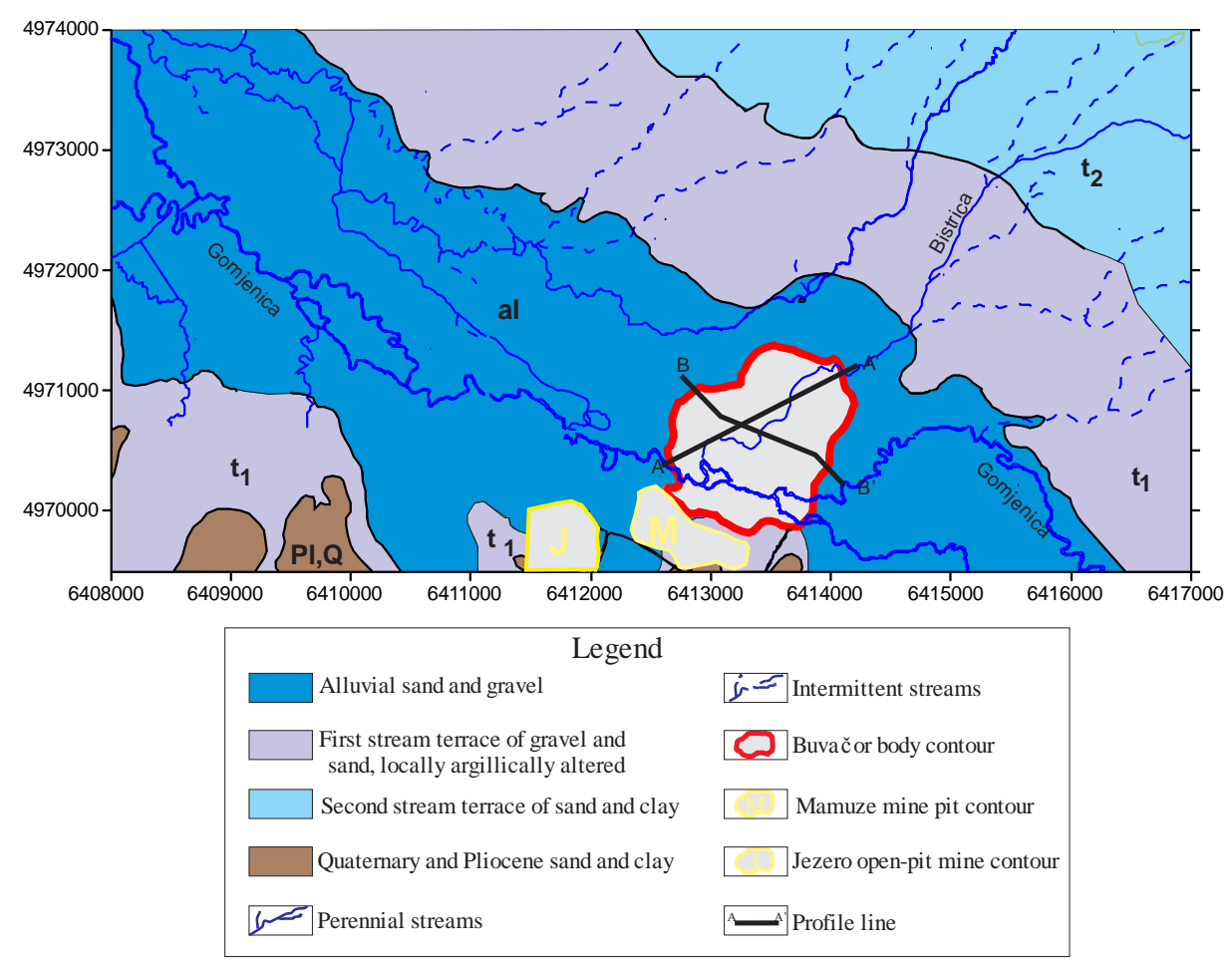

Figure 3. Hydrogeological map of the Buvač ore body

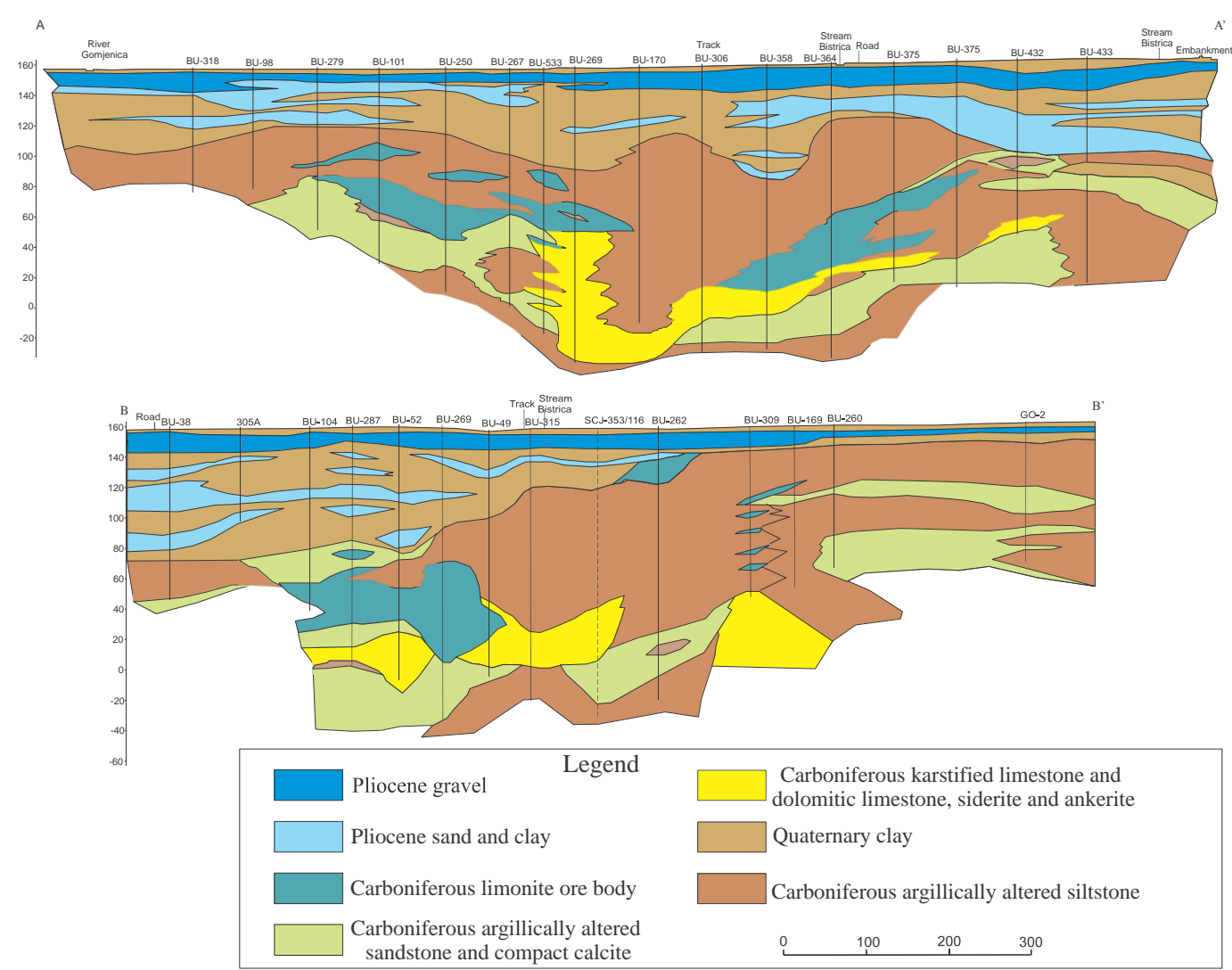

Figure 4. Hydrogeological sections A-A' and B-B'

Basic hydrogeological characteristics of the ore body are frequent alternation of permeable and impermeable rocks in the vertical section and four types of aquifers: alluvial aquifer, aquifer in Pliocene sands, aquifer in limonite ore body, and confined karstic aquifer bellow the limonite ore body. The effects of hydraulic communication 
between the aquifers in some areas are almost equal water head in each aquifer and uniform chemical composition of water, therefore marked three-dimensional movement of groundwater within the ore body [7]. Hydrogeological map (Fig. 3) shows the boundaries of Quaternary deposits and hydrogeological sections A-A' and B-B' (Fig. 4) show the relationship of the aquifers.

\section{HYDRODYNAMIC MODEL}

Groundwater flow in an unconfined aquifer may be approximately modeled by the nonlinear Boussinesq equation, assuming Dupuit's hypothesis of horizontal flow applies [8]. This equation in Cartesian coordinate system is shown below:

$$
\frac{\partial}{\partial x}\left(K_{x} \frac{\partial h}{\partial x}\right)+\frac{\partial}{\partial y}\left(K_{y} \frac{\partial h}{\partial y}\right)+\frac{\partial}{\partial z}\left(K_{z} \frac{\partial h}{\partial z}\right)-W=S_{s} \frac{\partial h}{\partial t}
$$

where $x, y$ and $z$ are coordinates of Cartesian coordinate system; $K_{x}, K_{y}$ and $K_{z}$ are the hydraulic conductivity along $x, y$ and $z$ coordinates which are assumed to be parallel to the major axes of hydraulic conductivity in $\mathrm{m} / \mathrm{s} ; h$ is hydraulic head in $\mathrm{m}$; $W$ is unit precipitation (precipitation per unit of horizontal spreading of the flow), represents the effective intensity of the vertical recharge in $\mathrm{m} / \mathrm{s}$ and $S_{s}$ is storage coefficient, --

The code selected to develop the numerical model was MODFLOW-2000; a modular, three-dimensional finite difference groundwater flow model developed by US Geological Survey [9]. The program used in this work is Groundwater Vistas 5.33b (Environmental Simulations International, Ltd.).

\section{Discretization of flow field}

A hydrodynamic model of the "Buvač" open-pit mine is designed to have eight layers in the vertical section. Each layer corresponds to a real stratum, schematized and delineated on the basis of observations and abundant field investigation data [10]. With respect to the natural strike and dip of the geologic units, the assigned extents of layers in plan and their respective thicknesses are different. Geometrization of the layer contours, their transposition into the coordinate system of the model, is based on abundant data from boreholes all over the research area (Fig. 2). The model layers, downward from the ground surface, are given in Tab. 1. The result of the schematized layers transposition into the model is represented by spatial distribution of the aquifer types in Fig. 5.

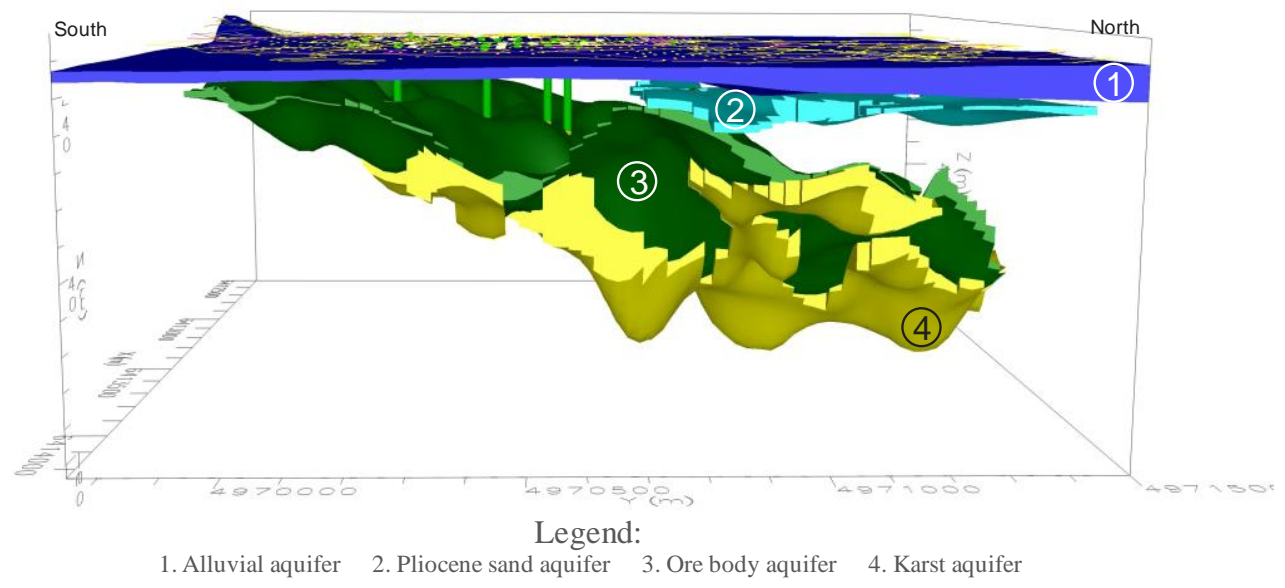

Figure 5. Three-dimensional view (eastern) of the system of aquifers in "Buvač" ore body 
Basic matrix dimensions for the research area are 2,000 $\mathrm{m} \times 1,750 \mathrm{~m}$ (Fig. 8). Cell size of the flow field discretization in plan is $25 \mathrm{~m} \mathrm{x} 25 \mathrm{~m}$, not further reduced with regard to the number and quality of available data [11].

\section{Hydraulic properties of porous rocks}

Hydraulic parameters for porous rocks are assigned as representative quantities to each discretization cell. Table 1 gives the initial values of the hydraulic parameters in the model [12].

Table 1. Initial values of hydraulic parameters

\begin{tabular}{|c|c|c|c|c|c|c|c|}
\hline Layer & $\begin{array}{l}\text { Hydrologic } \\
\text { function }\end{array}$ & $\begin{array}{l}\text { Lithostratigraphic } \\
\text { unit }\end{array}$ & $\begin{array}{c}\text { Hidraulic } \\
\text { conductivity } \\
\text { (at } \mathrm{x}, \mathrm{y} \text {-axis) }(\mathrm{m} / \mathrm{s})\end{array}$ & $\begin{array}{c}\text { Hidraulic } \\
\text { conductivity } \\
\text { (at z-axis) } \\
(\mathrm{m} / \mathrm{s})\end{array}$ & $\begin{array}{c}\text { Specific } \\
\text { storage } \\
(1 / \mathrm{m})\end{array}$ & $\begin{array}{l}\text { Specific } \\
\text { yield } \\
(-)\end{array}$ & $\begin{array}{c}\text { Total } \\
\text { porosity } \\
(-)\end{array}$ \\
\hline 1 & Impermeable & Clay overburden & $\begin{array}{l}8.50 \times 10^{-7}- \\
1.00 \times 10^{-6}\end{array}$ & $1.00 \times 10^{-6}$ & 0.001 & 0.037 & 0.45 \\
\hline 2 & Water-bearing & $\begin{array}{l}\text { Alluvial gravel } \\
\text { and sandy gravel }\end{array}$ & $\begin{array}{l}1.40 \times 10^{-4}- \\
3.80 \times 10^{-4}\end{array}$ & $1.00 \times 10^{-4}$ & $\begin{array}{c}2.25 \times 1 \\
0^{-5}\end{array}$ & 0.225 & 0.3 \\
\hline \multirow{2}{*}{3} & \multirow[t]{2}{*}{ Aquiclude } & $\begin{array}{l}\text { Clay and sandy } \\
\text { clay }\end{array}$ & $\begin{array}{c}6.20 \times 10^{-6} \\
-2.00 \times 10^{-5} \\
\end{array}$ & $1.00 \times 10^{-6}$ & $\begin{array}{c}5.00 \times 1 \\
0^{-5}\end{array}$ & 0.06 & 0.3 \\
\hline & & Part of ore body & $2.30 \times 10^{-4}$ & - & $\begin{array}{c}6.00 \times 1 \\
0^{-5}\end{array}$ & 0.06 & 0.27 \\
\hline \multirow{3}{*}{4} & \multirow{3}{*}{$\begin{array}{l}\text { Combines } \\
\text { impermeable } \\
\text { and permeable }\end{array}$} & $\begin{array}{l}\text { Clay and sandy } \\
\text { clay }\end{array}$ & $5.00 \times 10^{-6}$ & $1.00 \times 10^{-6}$ & $\begin{array}{c}5.00 \times 1 \\
0-5\end{array}$ & 0.06 & 0.3 \\
\hline & & Sand and gravel & $\begin{array}{l}1.00 \times 10^{-4}- \\
1.40 \times 10^{-4}\end{array}$ & $1.00 \times 10^{-4}$ & $\begin{array}{c}2.25 \times 1 \\
0^{-5}\end{array}$ & 0.23 & 0.35 \\
\hline & & Part of ore body & $2.3 \times 10^{-4}$ & $1.00 \times 10^{-4}$ & $\begin{array}{c}6.00 \times 1 \\
0^{-5}\end{array}$ & 0.06 & 0.27 \\
\hline \multirow{2}{*}{5} & \multirow[t]{2}{*}{$\begin{array}{l}\text { Largely } \\
\text { aquitard }\end{array}$} & $\begin{array}{l}\text { Clay and sandy } \\
\text { clay }\end{array}$ & $4.0 \times 10^{-6}$ & $1.00 \times 10^{-6}$ & $\begin{array}{c}5.00 \times 1 \\
0^{-5}\end{array}$ & 0.06 & 0.3 \\
\hline & & Part of ore body & $2.3 \times 10^{-4}$ & $1.00 \times 10^{-4}$ & $\begin{array}{c}6.00 \times 1 \\
0^{-5}\end{array}$ & 0.06 & 0.27 \\
\hline \multirow[b]{2}{*}{6} & \multirow[t]{2}{*}{$\begin{array}{l}\text { Largely } \\
\text { aquitard }\end{array}$} & $\begin{array}{l}\text { Argillic siltstone } \\
\text { and sandstone }\end{array}$ & $1.00 \times 10^{-6}$ & $1.00 \times 10^{-6}$ & $\begin{array}{c}6.30 \times 1 \\
0^{-5}\end{array}$ & 0.06 & 0.25 \\
\hline & & Part of ore body & $2.3 \times 10^{-4}$ & $1.00 \times 10^{-4}$ & $\begin{array}{c}6.00 \times 1 \\
0^{-5}\end{array}$ & 0.06 & 0.27 \\
\hline \multirow{3}{*}{7} & \multirow{3}{*}{$\begin{array}{l}\text { Combined } \\
\text { permeable-im } \\
\text { permeable } \\
\text { Aquifer in ore } \\
\text { body }\end{array}$} & $\begin{array}{l}\text { Limonite and fine } \\
\text { limonite }\end{array}$ & $\begin{array}{l}5.0 \times 10^{-5}- \\
2.40 \times 10^{-4}\end{array}$ & $1.00 \times 10^{-6}$ & $\begin{array}{c}5.00 \times 1 \\
0^{-5}\end{array}$ & 0.06 & 0.3 \\
\hline & & $\begin{array}{l}\text { Argillic siltstone } \\
\text { and sandstone }\end{array}$ & $1.5 \times 10^{-5}$ & $1.00 \times 10^{-6}$ & $\begin{array}{c}6.30 \times 1 \\
0^{-5} \\
\end{array}$ & 0.06 & 0.25 \\
\hline & & Limonite ore body & $2.3 \times 10^{-4}$ & $1.00 \times 10^{-4}$ & $\begin{array}{c}6.00 \times 1 \\
0^{-5}\end{array}$ & 0.06 & 0.27 \\
\hline \multirow[t]{2}{*}{8} & \multirow[t]{2}{*}{$\begin{array}{l}\text { Combined } \\
\text { permeable-im } \\
\text { permeable } \\
\text { Aquifer in } \\
\text { carbonate } \\
\text { rocks }\end{array}$} & $\begin{array}{l}\text { Limestone and } \\
\text { dolomitic } \\
\text { limestone, siderite } \\
\text { and ankerite in } \\
\text { argillic siltstone } \\
\text { and siltstone }\end{array}$ & $\begin{array}{c}3.52 \times 10^{-4}- \\
4.70 \times 10^{-4}\end{array}$ & $2.50 \times 10^{-4}$ & $\begin{array}{c}6.30 \times 1 \\
0^{-5}\end{array}$ & 0.06 & 0.35 \\
\hline & & $\begin{array}{l}\text { Argillic siltstone } \\
\text { and siltstone }\end{array}$ & $1.00 \times 10^{-6}$ & $1.00 \times 10^{-6}$ & $\begin{array}{c}6.30 \times 1 \\
0^{-5}\end{array}$ & 0.06 & 0.25 \\
\hline
\end{tabular}

\section{Boundary conditions}

Boundary conditions used in the hydrodynamic model of the Buvač ore body are the following: river boundary, vertical balance and general head boundary (GHB).

River boundary. Surface streams, primarily the rivers Gomjenica and Bistrica, are important for the groundwater flow system. For the influence of surface streams on groundwater flow, the monitoring data for a period of 2.5 years were collected and 
analysed. The analysis used mean monthly levels in the Gomjenica; data for the Bistrica stage were fewer than for the Gomjenica or for precipitation. All this was used as initial data for calibration of the model. A result of the model calibration was quantification of the Bistrica influence on the groundwater flow.

Figure 6 compares fluctuations of the measured level in the Gomjenica and water surface in alluvial gravels. Diagrams give monthly amounts of precipitation recorded at the Prijedor rain-gauging station also for 2.5 years. Influence of the Gomjenica on the groundwater flow is seen to exist in the alluvial aquifer, phase-shifted, delayed from the river stage fluctuation. The delay was considerable through the considered period, which suggested the likely high clogging of the riverbed (where it is cut in gravels). In contrast, groundwater in the alluvium reacts sooner to the changes caused by precipitation intensity.

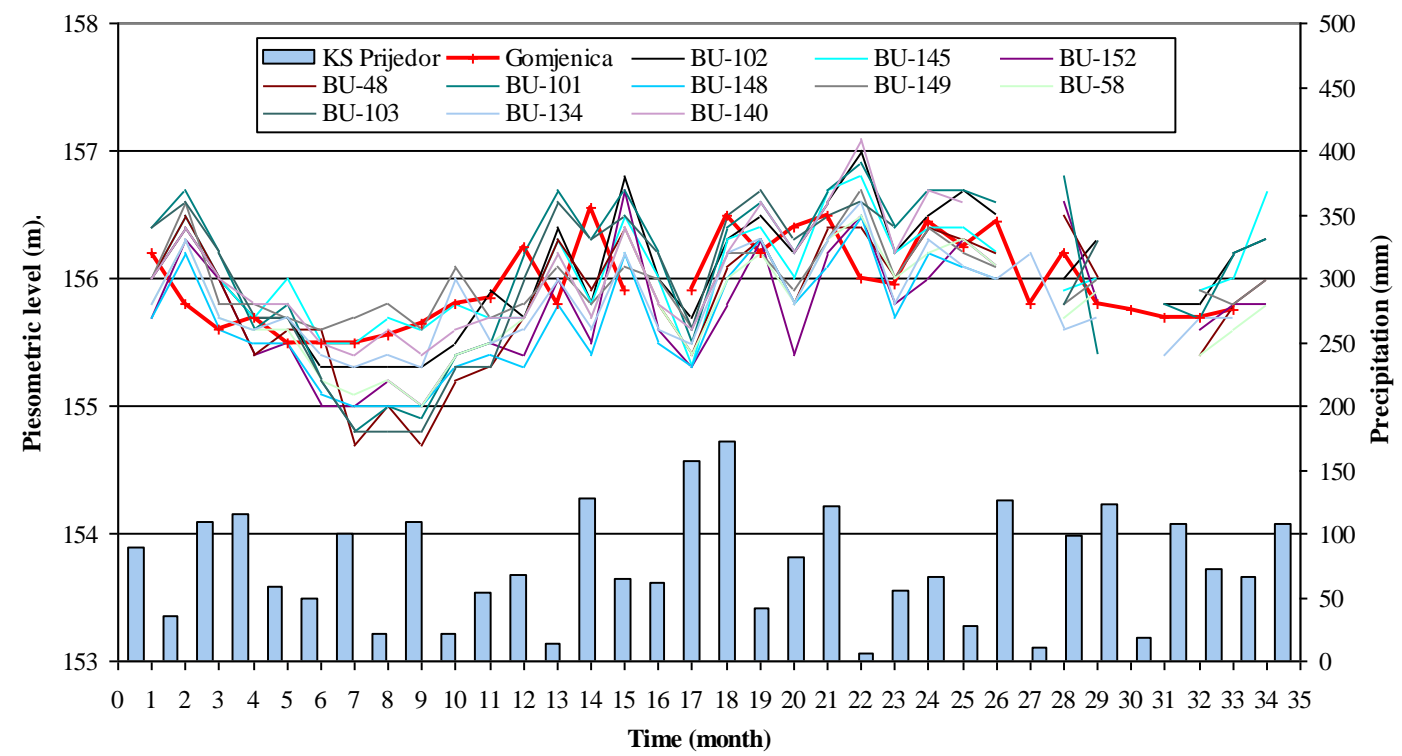

Figure 6. Fluctuations in the Gomjenica stage, precipitation and water table in alluvium

Figure 7 compares fluctuations of the measured level in the Gomjenica and water surface in limonite ore body. It shows fluctuations in the Gomjenica stage and in water tables within the limonite ore body. Groundwater surface oscillates with the fluctuation in the Gomjenica and "senses" effects of precipitation, which is evidence of the hydraulic communication between this aquifer and alluvial gravel.

The flow between Gomjenica nad Bistrica and aquifers was calculated through the Modlow RIVER package, on the basis of the following equation:

$$
Q_{R}=C_{R} \cdot\left(h_{R}-d\right)
$$

where $Q_{R}$ is the flow between river and the aquifer in $\mathrm{m}^{3} / \mathrm{s}$. The value of flow is positive if it is directed into aquifer. In above equation, $h_{R}$ is simulated aquifer head along the river in $\mathrm{m}$.

River conductance $C_{R}$ is given by equation:

$$
C_{R}=\frac{K \cdot L \cdot b}{d}
$$

where $K$ is hydraulic conductivity of river bottom sediments in $\mathrm{m} / \mathrm{s}, L$ is length of river cell in $\mathrm{m}, b$ is width of river cell in $\mathrm{m}$ and $d$ is thickness of river bottom sediments in $\mathrm{m}$. 


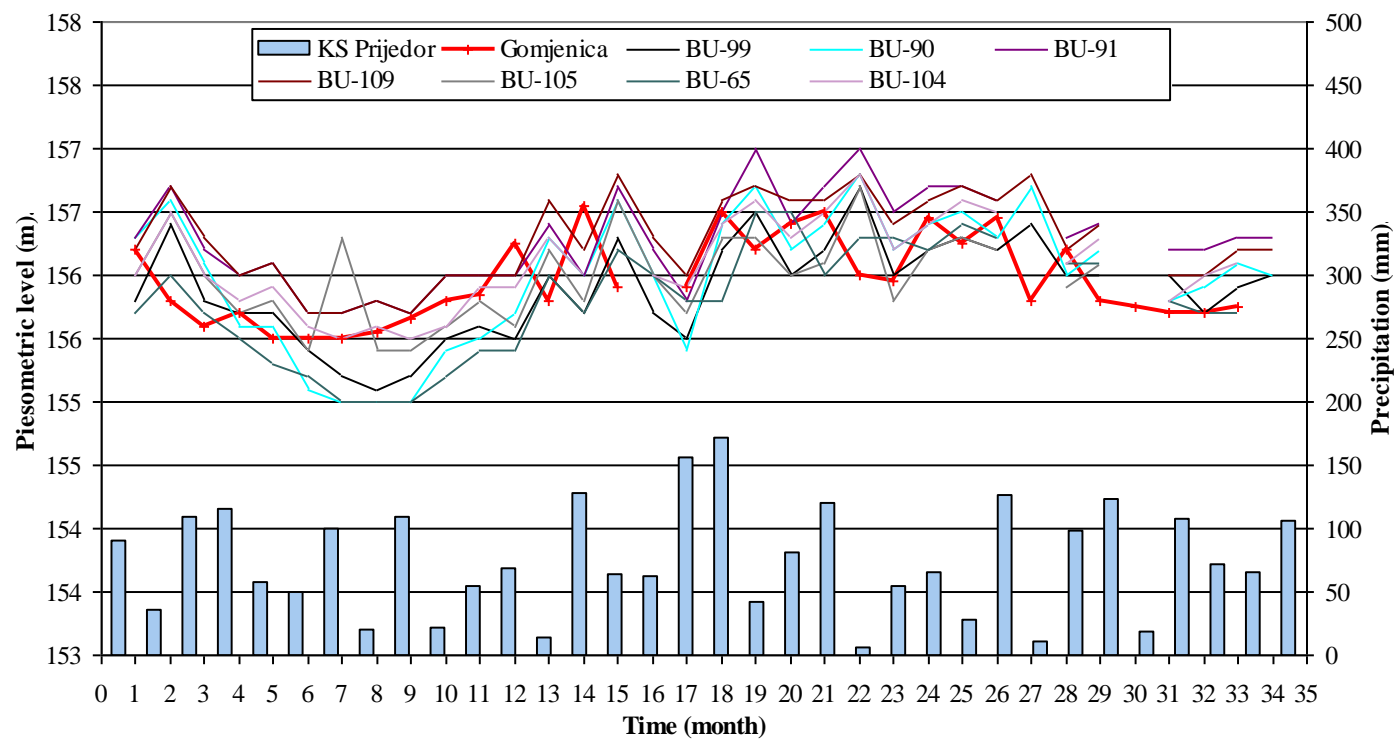

Figure 7. Fluctuations in the Gomjenica stage, precipitation and water table in limonite ore body

Hydraulic effect of surface streams, the rivers Gomjenica and Bistrica in particular because their influence on groundwater is the greatest within the extent of "Buvač" ore body, was simulated in the model as the river boundary, a boundary condition depending on the river stage.

In view of the riverbed elevations, or that rivers traverse aquifers and the overlying strata, the rivers as a boundary condition are assigned to second model layer - the alluvial gravels and sand. The direction of water flow from the river to the aquifer depends on the altitudinal difference between the groundwater surface and the river stage. Either the river feeds the aquifer, when water flows from the river into the aquifer if water in the river is higher than the groundwater surface, or the river drains groundwater from the aquifer to the river. This boundary condition is assigned to the first model layer (Fig. 8).

Vertical Balance. Total or vertical balance is an essential element of the groundwater budget. It is the effective, resultant infiltration, the amount of percolated precipitation, evaporation from groundwater surface and evapotranspiration. Besides, also very important are depth to groundwater, moisture and lithology of the overlying strata. Effective percolation is considerable in the study area at the conditions for which data were available, because groundwater levels are at small depths from ground surface. Average percolation is $5 \mathrm{l} / \mathrm{s} / \mathrm{km}^{2}$, or $14.29 \%$ of the amount of precipitation. Data used for the mathematical model were precipitation records from the Prijedor rain-gauging station, averaged out to monthly level.

Like the river boundary condition, the influence of precipitation and evaporation expressed as effective percolation in real monthly amounts is assigned for the whole groundwater flow simulation period.

General Head Boundary (GHB). General Head Boundary is similar in mathematical terms the river boundary. It is used to simulate the impact of external sources of groundwater located outside the flow field covered by mathematical model. Flow rate to or from the observed model's cell is calculated by the formula:

$$
Q_{G H B}=C_{G H B}\left(H_{G H B}-h\right)
$$


where $Q_{G H B}$ is flow rate to or from model's cell in $\mathrm{m}^{3} / \mathrm{s} ; H_{G H B}$ is hydraulic head in model's cell in $\mathrm{m}$; $h$ is calculated value of hydraulic head in $\mathrm{m}$ and $C_{G H B}$ is conductance of model's cell $\mathrm{m}^{2} / \mathrm{s}$.

The influence of karstified limestone beneath the ore body is assigned to the model through this boundary condition, and this only in the eighth layer of karstified rocks in the north where they are actually replenished, and in the second model layer with alluvial gravel and sands in the east (Fig. 8).

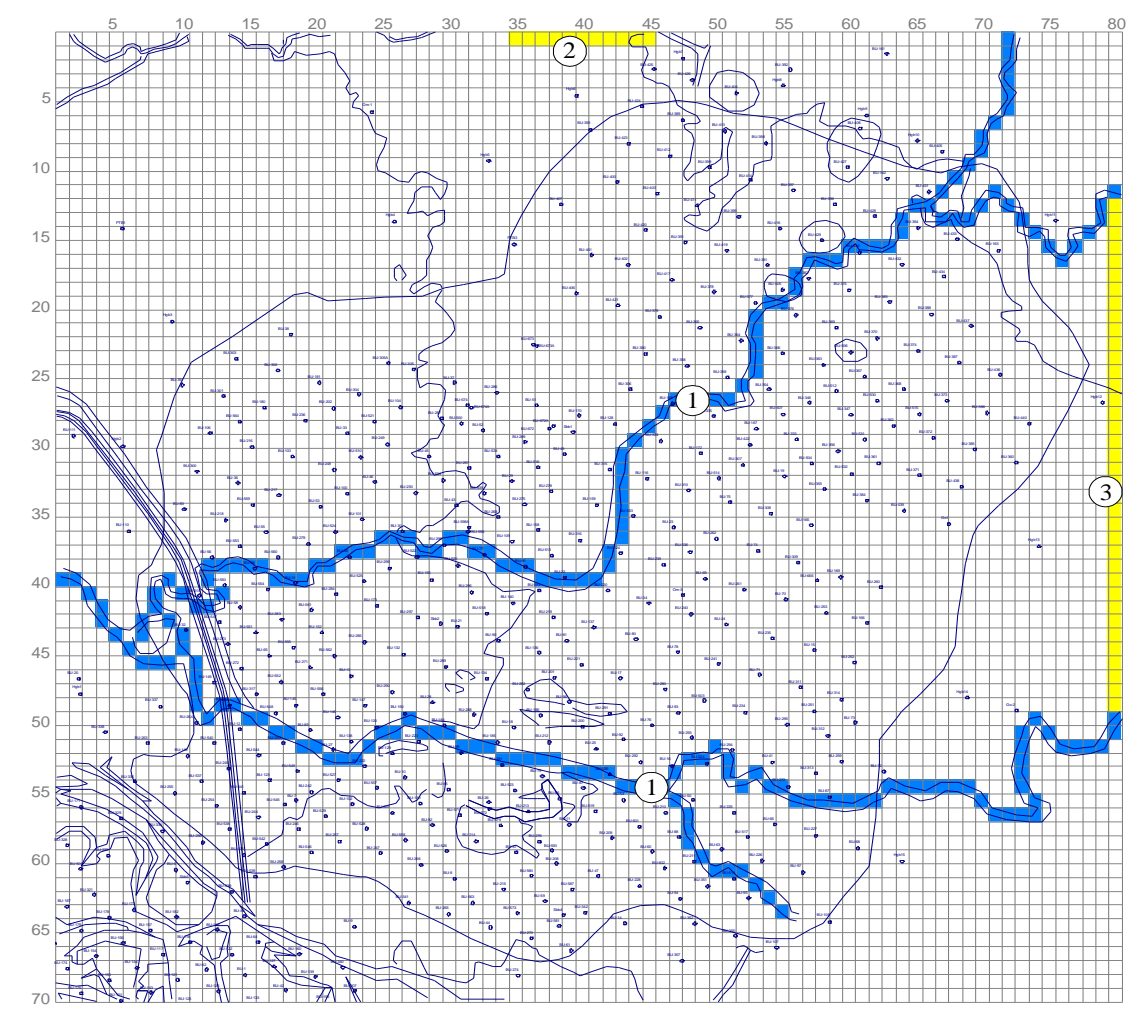

Figure 8 . River boundary and general load boundary conditions of the model

Legend: 1. River boundary condition for alluvial gravel and sand; 2. GHB for carbonate rocks; 3. GHB for alluvial gravel and sand

\section{MODEL CALIBRATION}

The model was calibrated under the condition of unsteady flow with the one-month time step through 2.5 years. Groundwater flow was calculated and simulated real flow, under pressure, or free water table, individually in each discretization field, with the model flow conditions simulating the real conditions. For verification of results during the model calibration, mainly the water table records were used. Figure 9 shows sites of the observation wells in which groundwater levels were measured. Initial values of natural rock characteristics (permeability and specific storage or effective porosity) and characteristics of the cell to which the river boundary condition was attributed were modified during the calibration process. Figure 9 shows also the pattern of groundwater levels for the ore body, resulting from the model calibration. The agreement of registered and calibrated groundwater levels was fairly good $( \pm 0.2 \mathrm{~m})$. For the purpose of a more detailed analysis, Fig. 10 shows recorded and calculated groundwater levels during the simulation for wells in the alluvial aquifer, and Fig. 11 for aquifer in the limonite ore body. Figure 10 show a generally good accordance of the mathematical simulation results 
with the measured groundwater levels for the investigated area. However, there are a few deviations, in locations of BU-48, BU-58 and BU-148, where the calculated hydrographs are higher than those measured by $30 \mathrm{~cm}$ at the most. A better agreement could not be achieved with the given quality of the available data. Any reduction of the discrepancy between the calculated and measured groundwater levels would be associated only with local changes in the hydraulic properties and would not affect the flow pattern in the investigated area.

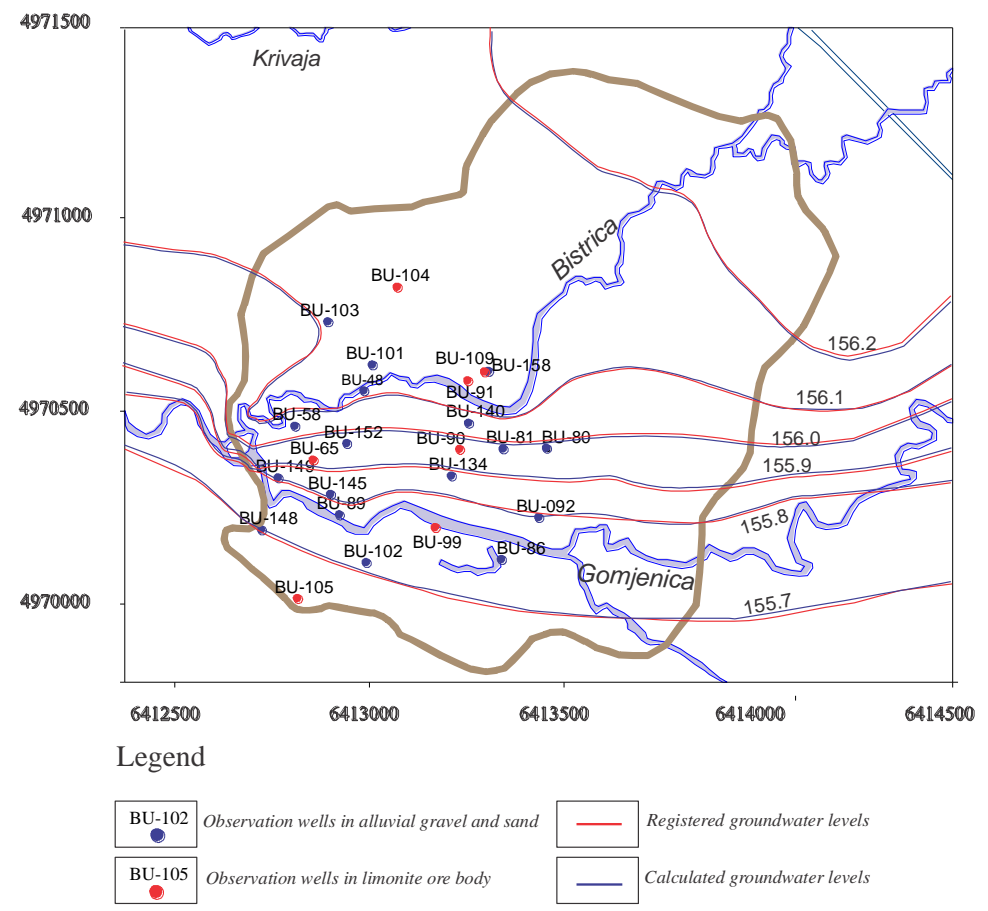

Figure 9. Map of observation wells and groundwater levels in the end of the model calibration period

The presented groundwater surface hydrographs in the limonite body (Fig. 11) show good correspondence of the calculated and registered stages.
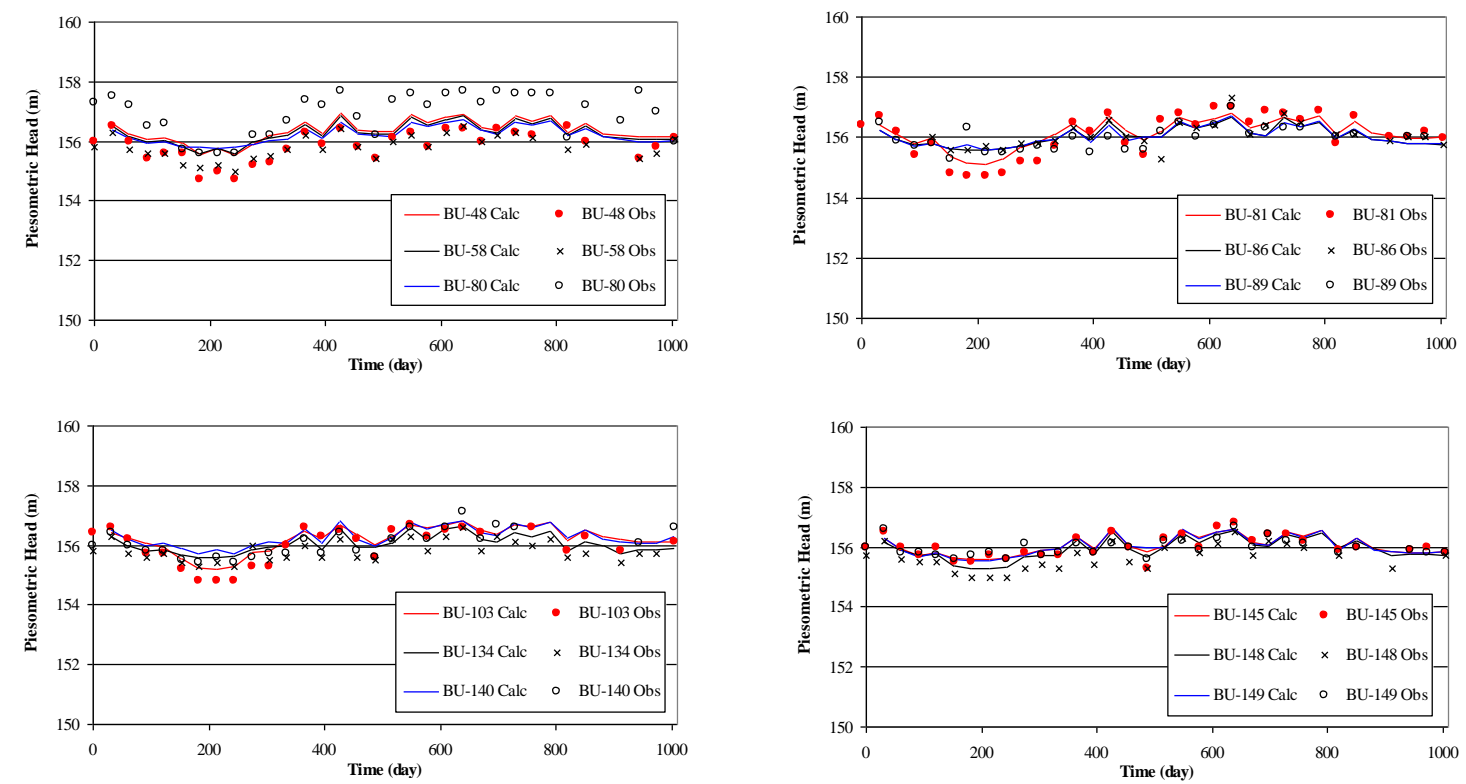

Figure 10. Measured and calculated well hydrographs for alluvial aquifer 

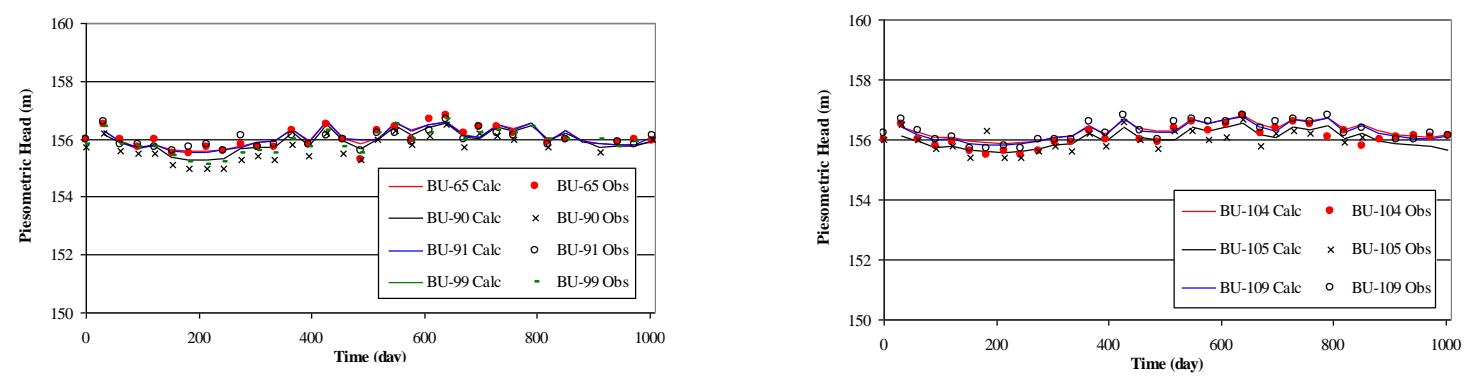

Figure 11. Measured and calculated well hydrographs for limonite body

\section{GROUNDWATER BALANCE}

A result of model calibration is the quantification of groundwater balance elements (Tab. 2).

The groundwater balance in the end of the period used for calibration led to the conclusion that the alluvial aquifer is recharged from the rivers Bistrica and Gomjenica, from precipitation and in part from subsurface inflow. The karstified limestone aquifer is subsurface recharged from the north, and the limonite ore body includes an underground reservoir naturally fed from water in carbonate rocks and partly from alluvial aquifers. Alluvial groundwater partly drains to the rivers and partly through the SW model boundary and seepage to ore body Mamuze. Groundwater in carbonate rocks drains partly into the limonite ore body. Table 2 gives main elements of the groundwater balance in the period considered by calibration.

Table 2. Groundwater balance elements for the area of the Buvač mineral deposit

\begin{tabular}{l|cc}
\hline \multicolumn{1}{c|}{ Boundary condition } & Model inflow, $/ / s$ & Model outflow (drainage), l/s \\
\hline Gomjenica River & 8.32 & 10.52 \\
Bistrica River & 6.92 & 7.58 \\
$\begin{array}{l}\text { Subsurface inflow from north } \\
\text { (alluvial deposits) }\end{array}$ & 2.26 & - \\
$\begin{array}{l}\text { Subsurface inflow from north } \\
\text { (carbonate rocks) }\end{array}$ & 4.38 & - \\
$\begin{array}{l}\text { Subsurface inflow from east } \\
\text { (alluvial deposits) }\end{array}$ & 2.57 & \\
$\begin{array}{l}\text { Subsurface inflow from south } \\
\text { (alluvial deposits) }\end{array}$ & 3.22 & \\
$\begin{array}{l}\text { Subsurface outflow to west } \\
\text { (alluvial deposits) }\end{array}$ & - & 8.48 \\
$\begin{array}{l}\text { Subsurface outflow to south } \\
\text { in ore body Mamuze }\end{array}$ & & 4.81 \\
Percolation from precipitation & 4.22 & - \\
\hline Total & 31.89 & 31.39 \\
\hline
\end{tabular}

\section{CONCLUSION}

The spatial pattern of groundwater flow is related to the vertical lithological stratification and the variable horizontal extent of geologic units. This is particularly true of the ore body and alluvial sediments and of the ore body and limestone contact areas. This was the reason why we developed an eight-layer model. Verification of the model calibration results used well records of the groundwater tables. Mathematical simulation results agreed fairly well with the water table records. 
The results of the model calibration are quantification of the Bistrica and Gomjenica influence on the groundwater flow and determining the groundwater balance elements for the Buvač ore body. As the result of the model calibration, it has been quantified that the karstified limestone aquifer is subsurface recharged from the north $(4.38 \mathrm{l} / \mathrm{s})$. The account of percolation from precipitation is $4.22 \mathrm{l} / \mathrm{s}$, water infiltration (summary) of the Bistrica and Gomjenica rivers is 15.24 1/s. It has also been confirmed that aquifers are drained by subsurface outflow from west $(8.48 \mathrm{l} / \mathrm{s})$ and south $(4.81 \mathrm{l} / \mathrm{s})$. Total model inflow is $31.89 \mathrm{l} / \mathrm{s}$, and model outflow is $31.39 \mathrm{l} / \mathrm{s}$.

The hydrodynamic model so calibrated is an initial tool in forecasting groundwater behaviour for an optimum protection of the mine pit.

\section{ACKNOWLEDGMENTS}

The author is very grateful to the Ministry of Education and Science of Republic of Serbia for financing projects 176022, III-43004 and 33039.

\section{REFERENCES:}

1. Hanna, T.M., Azrag, E.A., Atkinson, L.C., Use of an analytical solution for preliminary estimates of groundwater inflow to a pit. Mining Engineering 46(2), pp.149-152, 1994.

2. Marinelli, F., Niccoli, W.L., Simple analytical equations for estimating ground water inflow to a mine pit. Ground Water 38 (2), pp.311-314, 2000., http://dx.doi.org/10.1111/j.1745-6584.2000.tb00342.x

3. Shevenell, L., Analytical method for predicting filling rates of mining pit lakes: example from the Getchell Mine, Nevada. Mining Engineering 52(3), pp.53-60, 2000.

4. Rapantova, N., Grmela, A., Vojtek, A., Halir, J., Michalek, B., Ground Water Flow Modelling Applications in Mining Hydrogeology. Mine Water and the Environment, Vol. 26, Iss. 4, pp.264-270, 2007., http://dx.doi.org/10.1007/s10230-007-0017-1

5. Daozhong, C., Quingli, Z., Jie, W., Xiaozhi, Z.: Comparative Analysis of Ecological Rucksack Between Open-pit and Underground Coal Mine. Mining Science and Technology, Vol. 20, Iss. 2, pp.266-270, 2010.

6. Adams, R., Younger, P.L., A strategy for modelling ground waterrebound in abandoned deep mine systems. Ground Water 39(2), pp.249-261, 2001., http://dx.doi.org/10.1111/j.1745-6584.2001.tb02306.x

7. Bajic, D., Polomcic, D, 3D Hydrogeological model of the limonite ore body "Buvac" (Republika Srpska, Bosnia and Herzegovina). IV International Conference "Coal 2008", Belgrade, pp.1-9, 2008.

8. Marsily, G., Quantitative Hy-drogeology. Groundwater Hydro-logy for Engineers. Academic Press, Inc.San Diego, CA, USA, 1986.

9. Harbaugh, A.W., Banta, E.R., Hill, M.C. and McDonald, M.G., MODFLOW-2000: The U.S. Geological Survey Modular Ground-Water Model. User Guide to Modularization Concepts and the Ground-Water Flow Process, U.S. Geological Survey Open-File Report 00-92, Reston, VA, USA, pp.121, 2000.

10. Polomcic, D., Schematization types of hydrogeological system for setting up the hydrodynamic model. Proceedings of the XIII Yugoslav symposium of hydrogeology and engineering geology, Herceg Novi, pp.389-396, 2002.

11. Polomcic D., The influence of size of discretization of space and time on the accuracy of results in the conception of the hydrodynamic model, Papers of Geoinstitut, Belgrade, pp.197-209, 2004. 
12. Polomcic, D., Dragisic,, V. and Zivanovic, V., Hydrodynamic model of the groundwater source for water supply of Prijedor town (Republic of Srpska). Int. Conference \& Field Seminar - Water Resources \& Environmental Problems in Karst, CVIJIĆ, Beograd, pp.539-544, 2005.

Paper submitted: 20.02.2013

Paper revised: 03.04.2013

Paper accepted: 18.04.2013 